\title{
Connections of the superior colliculus to shoulder muscles of the rat: a dual tracing study
}

\author{
J. M. Rubelowski ${ }^{1}$, M. Menge ${ }^{1}$, C. Distler ${ }^{1}$, M. Rothermel ${ }^{2}$ and K.-P. Hoffmann ${ }^{3 *}$ \\ ${ }^{1}$ Allgemeine Zoologie and Neurobiologie, Ruhr-University Bochum, Bochum, Germany \\ 2 Brain Institute and Department of Physiology, School of Medicine, University of Utah, Salt Lake City, UT, USA \\ 3 Tierphysiologie, Ruhr-University Bochum, Bochum, Germany
}

Edited by:

Alfonso Fairén, University Miguel

Hernandez, Spain

Reviewed by:

Alino Martinez-Marcos, Universidad

de Castilla, Spain

Peter Redgrave, University of

Sheffield, UK

*Correspondence:

K.-P. Hoffmann, Tierphysiologie,

Ruhr-University Bochum,

Universitätsstr. 150, ND 5/26, 44780

Bochum, Germany

e-mail:kphoffm@gmail.com
Previous investigations indicate that the superior colliculus (SC) is involved in the initiation and execution of forelimb movements. In the present study we investigated the tectofugal, in particular the tecto-reticulo-spinal projections to the shoulder and arm muscles in the rat. We simultaneously retrogradely labeled the premotor neurons in the brainstem by injection of the pseudorabies virus PrV Bartha 614 into the $\mathrm{m}$. rhomboideus minor and $\mathrm{m}$. acromiodeltoideus, and anterogradely visualized the tectofugal projections by intracollicular injection of the tracer FITC dextrane. Our results demonstrate that the connection of the SC to the skeletal muscles of the forelimb is at least trisynaptic. This was confirmed by long survival times after virus injections into the muscles (98-101 h) after which numerous neurons in the deep layers of the SC were labeled. Transsynaptically retrogradely labeled brainstem neurons connected disynaptically to the injected muscles with adjacent tectal terminals were predominantly located in the gigantocellular nuclear complex of the reticular formation. In addition, putative relay neurons were found in the caudal part of the pontine reticular nucleus. Both tectal projections to the nucleus gigantocellularis and the pontine reticular nucleus were bilateral but ipsilaterally biased. We suggest this projection to be involved in more global functions in motivated behavior like general arousal allowing fast voluntary motor activity.

Keywords: superior colliculus, $m$. rhomboideus, $m$. acromiodeltoideus, m. trapezius, pseudorabies virus, forelimb movements

\begin{abstract}
Abbreviations: 3, nucleus oculomotorius; 7, nucleus facialis; $7 \mathrm{n}$, nervus facialis; 12, nucleus hypoglossus; A, aqueduct; Amb, nucleus ambiens; AP, area postrema; Ce, cerebellum; Cg1,3, cingulate cortex, area 1,3; CGPn, pontine central gray; $\mathrm{Cu}$, nucleus cuneatus; $\mathrm{Cx}$, cortex; DMTg, dorsomedial tegmental area; DPGi, nucleus paragigantocellularis pars dorsalis; DR, dorsal raphe nucleus; DTg, nucleus tegmentalis dorsalis; Ecu, nucleus cuneatus externus; Fr2, frontal cortex, area 2; $\mathrm{Gi}$, nucleus gigantocellularis pars reticularis; GiA, nucleus gigantocellularis pars reticularis alpha; GiV, nucleus gigantocellularis pars reticularis pars ventralis; $\mathrm{Gr}$, nucleus gracilis; $\mathrm{H}$, hippocampus; Hab, habenulae; IC, inferior colliculus; Int, nucleus interpositus; IO, oliva inferior; IRt, nucleus reticularis intermedialis; LDTg, nucleus tegmentalis laterodorsalis; LGN, nucleus geniculatus lateralis; LPB, nucleus parabrachialis lateralis; LPGi, nucleus paragigantocellularis pars lateralis; LRt, nucleus reticularis pars lateralis; LVe, nucleus vestibularis lateralis; Md, nucleus reticularis medullaris; MdD, nucleus reticularis medullaris pars dorsalis; MdV, nucleus reticularis medullaris pars ventralis; MGN, nucleus geniculatus medialis; MM, mammillary body; Me5, nucleus trigeminus mesencephalicus; Mo5, nucleus trigeminus motorius; MVe, nucleus vestibularis medialis; PAG, periaqueductal gray; PCRt, nucleus reticularis parvocellularis; PDTg, nucleus tegmentalis posterodorsalis; PM, premammillary body; PMn, paramedian reticular nucleus; $\mathrm{PnC}$, nucleus reticularis pontis pars caudalis; $\mathrm{PnO}$, nucleus reticularis pontis pars oralis; PnV, nucleus reticularis pontis pars ventralis; pons, nuclei pontis; Pr5VL, nucleus trigeminus principalis ventrolateralis; $\mathrm{PrO}$, area praeoptica; $\mathrm{Pt}$, pretectum; Py, pyramidal tract; R, nucleus ruber; raphe, raphe nuclei; RVL, nucleus reticularis rostroventrolateralis; S, septum; SC, superior colliculus; SGe, nucleus supragenualis; SNC, substantia nigra pars compacta; SNR, substantia nigra pars reticularis; $\mathrm{SO}$, oliva superior; Sol, nucleus tractus solitarii; $\mathrm{Sp} 5 \mathrm{C}$, nucleus trigeminus spinalis pars caudalis; Sp5I, nucleus trigeminus spinalis pars interpolaris; Sp5O, nucleus trigeminus spinalis pars oralis; SPVe, nucleus vestibularis spinalis; STH, nucleus subthalamicus; SubC, nucleus subcoeruleus; SubCA, nucleus subcoeruleus pars anterior; SubCD, nucleus subcoeruleus pars dorsalis; SubCV, nucleus subcoeruleus pars ventralis; SuVe, nucleus vestibularis superior; Tz, trapezoid body.
\end{abstract}

\section{INTRODUCTION}

It is well known that the superior colliculus (SC) plays a key role in the visual grasp reflex involving movement of the eyes, the head, and the body (Akert, 1949; for a recent review see White and Munoz, 2011). More recently it has been shown that specific neurons in the intermediate and deep layers of SC are involved in reach movements of the arm (Werner, 1993; Werner et al., 1997a,b; Stuphorn et al., 2000). There are at least two potential pathways connecting the SC with the motoneurons in the spinal cord, the tectospinal tract and the tecto-reticulo-spinal tract.

The tectospinal tract is a very conserved structure present in all mammals investigated so far although it is better developed in predatory than in less predatory species (Waldron and Gwyn, 1969; Nudo and Masterton, 1988, 1989; Barton and Dean, 1993). It originates in the intermediate and deep layers mostly of the lateral SC and terminates almost exclusively on interneurons in the upper cervical cord whose motoneurons innervate neck muscles, and in the lower cervical enlargement which innervates the upper limb (Anderson et al., 1972; Rhoades and DellaCroce, 1980; Murray and Coulter, 1982; Nudo and Masterton, 1988; Rose et al., 1991; Xiulai et al., 1994; Muto et al., 1996; Yasui et al., 1998; Meredith et al., 2001). Another important tecto-spinal termination target are the propriospinal neurons in the C3-C4 segments of the cervical cord which govern target reaching of the forelimb 
(Illert et al., 1978; Alstermark et al., 2007; Alstermark and Isa, 2012).

The tecto-reticulo-spinal tract also originates in the intermediate and deep layers of the SC, involves the tegmental and pontine reticular formation and also ends in the upper cervical spinal cord (Nudo and Masterton, 1988; Keay et al., 1990; Redgrave et al., 1990; Yasui et al., 1998; Meredith et al., 2001) contacting at least in part the motoneurons of head extensor muscles (Anderson et al., 1971). In fact, the cells of origin of the tectospinal and the tecto-reticulo-spinal tract overlap to some degree in the intermediate and deep layers of the lateral SC (Yasui et al., 1998). Electrical stimulation of the SC and the dorsal tegmentum in the cat activates reticulospinal neurons (Schäfer, 1970; Udo and Mano, 1970) that in turn activate motoneurons of the flexor and extensor muscles of the hind- and forelimb (Grillner and Lund, 1968). Even though an at least disynaptic projection from the SC to the motoneurons of the fore- and hindlimb muscles was proposed based on electrical stimulation experiments (Anderson et al., 1972) the anatomical connection has yet to be demonstrated. This is the main aim of the present study.

During the last $20+$ years viruses have been established as efficient transneuronal anterograde and retrograde tracers (Kuypers and Ugolini, 1990; Ugolini, 1995, 2010). In this study we used the attenuated pseudorabies virus PrV Bartha to transsynaptically label the chain of neurons connecting the SC with the shoulder and arm muscles. PrV Bartha is less virulent compared to wildtype $\operatorname{PrV}$ and a selective retrograde transsynaptic tracer, only propagating in the retrograde direction of information flow within the nervous system (Enquist, 2002). PrV Bartha has been extensively used in tracing studies of various neuronal circuits (e.g., Enquist, 1994, 2002; Marson and McKenna, 1996; Yang et al., 1999; DeFalco et al., 2001; Pickard et al., 2002; Cuthbertson et al., 2003; Damann et al., 2006; Kerman, 2008).

In our study we anterogradely labeled the first tectofugal synaptic sites using the tracer FITC dextrane, and premotor neurons of forelimb muscles by infection of proximal shoulder and arm muscles using PrV Bartha. We chose the m. trapezius, m. acromiodeltoideus, and m. rhomboideus because earlier experiments showed a high correlation of reach-related neuronal activity in the SC with the electromyographic activity of these muscles during a reach task in monkeys (Werner et al., 1997a; Stuphorn et al., 1999). With this approach we could demonstrate an at least trisynaptic signal transmission from the SC via relay neurons in the reticular nuclear complex and motor neurons in the spinal cord to the shoulder muscles.

\section{MATERIALS AND METHODS}

All experiments were approved by the local authorities (Regierungspräsidium Arnsberg, local ethics committee) and were performed according to the European Communities Council Directive RL 2010/63/EC, the Deutsche Tierschutzgesetz of 7.26.2002, and the NIH guidelines for care and use of animals for experimental procedures.

\section{ANIMALS}

Altogether, 22 Wistar rats 5-12 weeks old and weighing 127-310 g were used. All animals had been bred and raised in the animal facility of the Department of Zoology and Neurobiology in an enriched environment.

In a first series of experiments ( 8 animals) we determined the time course of the retrograde propagation of the pseudorabies virus PrV-Bartha-614 in the tectofugal projection to the arm- and shoulder muscles. Subsequently, virus injections into the musculature were combined with FITC dextrane injections into the SC (14 animals) to visualize tectofugal projections.

\section{RECOMBINANT VIRUS}

An attenuated recombinant strain of pseudorabies virus $\operatorname{PrV}$ Bartha expressing "monomeric red fluorescent protein 1" mRFP1 (Banfield et al., 2003) was used in the present study. The PrV614 was propagated in monolayers of porcine kidney (PK15) cells, and assayed using a standard plaque assay. Viral stocks containing $8.3 \times 10^{8} \mathrm{pfu} / \mathrm{ml}$ and $1.9 \times 10^{8} \mathrm{pfu} / \mathrm{ml}$ [plaque forming units (pfu)] were aliquoted in $100 \mu \mathrm{l}$ volumes and stored at $-80^{\circ} \mathrm{C}$. At the time of injection, viral aliquots were removed from the freezer and kept on ice until use.

\section{SURGERY}

The animals were premedicated with $0.05 \mathrm{mg}$ atropine sulphate i.m. and initially anaesthetized with $90 \mathrm{mg} / \mathrm{kg}$ ketamine hydrochloride (Ketavet 10\%, cp-pharma) and $5 \mathrm{mg} / \mathrm{kg}$ xylacine hydrochloride (Rompun ${ }^{\circledR} 2 \%$, Bayer). To ensure deep analgesia the animals received a bolus of $3 \mu \mathrm{g} / \mathrm{kg}$ fentanyl citrate (Fentanyl ${ }^{\circledR}$, Jansen-Cilag). During the experiments, anaesthesia was maintained by boluses of $0.1 \mathrm{ml}$ of $1 \%$ ketamine as needed. Body temperature was maintained at $36-37.5^{\circ}$, and heart rate was monitored during the whole experiment. Corneae were protected with ointment (VitA-POS ${ }^{\circledR}$, Ursapharm).

\section{TRACER INJECTIONS INTO THE SUPERIOR COLLICULUS (SC)}

After additional local anaesthesia with $0.1 \mathrm{ml}$ bupivacain hydrochloride (Bupivacain ${ }^{\circledR}$ 0.5\%, Jenapharm) the animals were placed in the stereotaxic apparatus, the skin overlying the skull was cut and a craniotomy was performed to allow access to the right SC. After localizing the SC electrophysiologically, the recording electrode was moved until a receptive field position in the lateral SC was reached (elevation 0 to $-10^{\circ}$, azimuth $\left.70-90^{\circ}\right)$. In order to verify the location of tectospinal neurons, in 2 animals we electrically stimulated the right SC using low impedance recording electrodes or injection pipettes. Electrical stimuli consisted of single pulses $(0.12 \mathrm{~ms}$ wide, $0.1-1.2 \mathrm{~mA})$ or pulse trains (166 and $330 \mathrm{~Hz}, 0.04-0.2 \mathrm{~mA}, 200 \mathrm{~ms}$ duration). The electromyogram (EMG) of the left $\mathrm{m}$. acromiotrapezius was recorded using silver wire electrodes.

Then the recording or stimulating electrode was replaced with a glass pipette connected to a Hamilton microsyringe, and 0.6-1.0 $\mu \mathrm{l}$ of dextrane (MW 3000) conjugated to fluorescein isothiocyanate (FITC) (15\% in $0.1 \mathrm{~m}$ citrate- $\mathrm{NaOH}, \mathrm{pH} 3.0)$ was injected at depths ranging from 400 to $2000 \mu \mathrm{m}$ below the SC surface. A second injection was placed at 300-900 $\mu \mathrm{m}$ distance from the first injection. After completion of the injections the wound was closed in appropriate layers and protected with ointment containing neomycin sulphate (Nebacetin ${ }^{\circledR}$, Yamanouchi Pharma). After full recovery, the animals were returned to their home cage. 


\section{VIRUS INJECTIONS INTO THE SHOULDER MUSCLES}

Forty-eight (to seventy-one) hours after the SC-injections the animals were re-anaesthetized as above. After additional local anaesthesia the skin overlying the left shoulder i.e., contralateral to the SC injections was cut and the $\mathrm{m}$. trapezius, the $\mathrm{m}$. acromiodeltoideus or the m. rhomboideus minor were exposed. In order to place the virus close to the innervation sites by the accessory nerve (m. trapezius), the axillary nerve (m. acromiodeltoideus), and the scapular nerve (m. rhomboideus) (Greene, 1935), respectively, injections were placed laterally in the m. trapezius, ventrally in the $\mathrm{m}$. acromiodeltoideus, or medially and ventrally in the m. rhomboideus (Figure 1). Using a Hamilton microsyringe with a tapered tip $6 \mu \mathrm{l}$ of the virus suspension PrV614 thawed immediately before the application were injected into the muscle. The needle was left in space for several minutes after the injection to avoid virus spill along the penetration track. Afterwards, the wound was closed in appropriate layers. After full recovery, the animals were returned to a cage in the biosafety level 2 lab and closely monitored during the entire survival time.

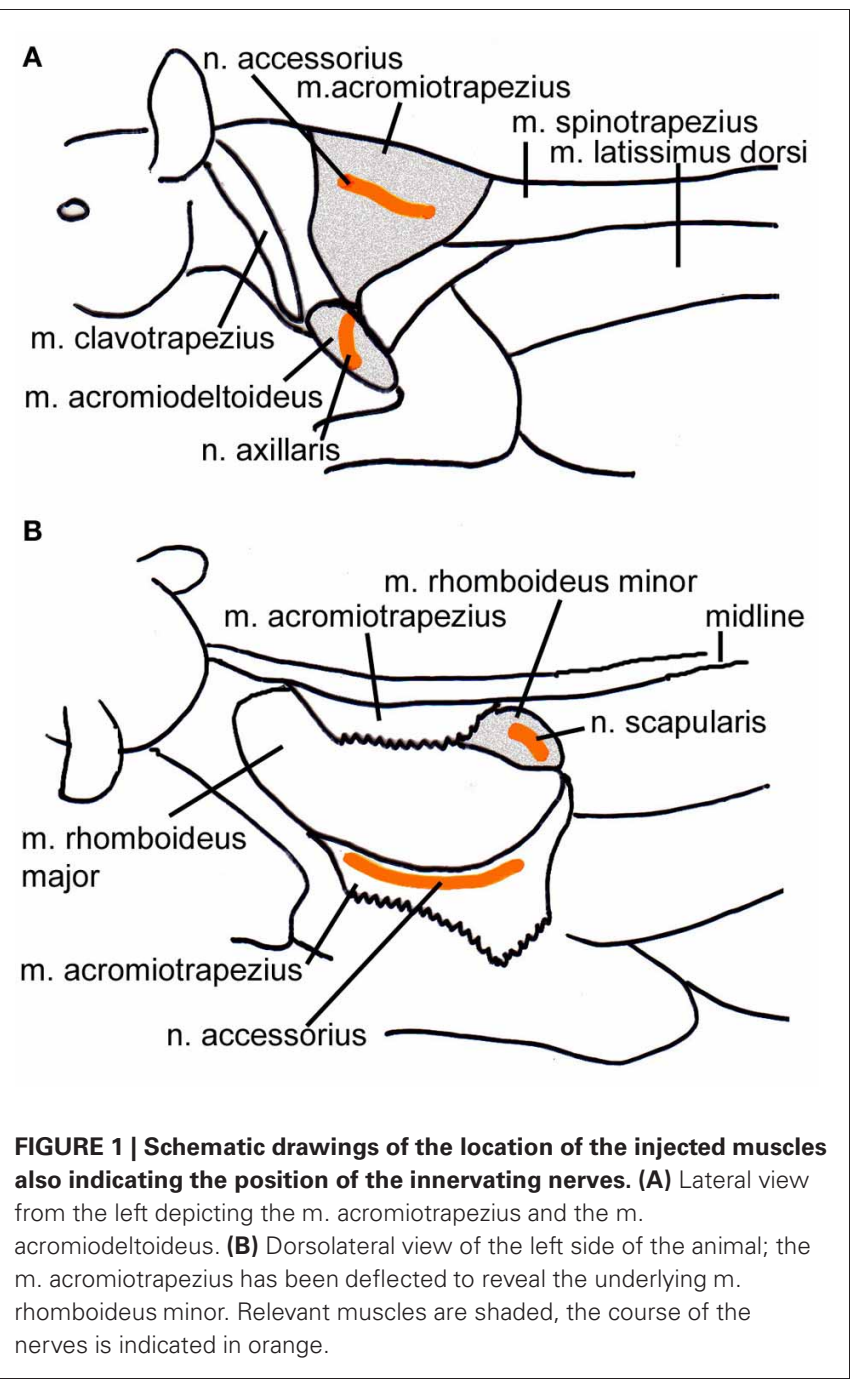

\section{PERFUSION, HISTOLOGICAL PROCESSING AND ANALYSIS}

Eighty to one hundred hours (prior experiments) and $73-79 \mathrm{~h}$ (dual tracing experiments) after the muscle injections the animals were deeply anaesthetized with an overdose of halothane and transcardially perfused with $0.9 \% \mathrm{NaCl}$ and $0.1 \%$ procaine hydrochloride, followed by $4 \%$ paraformaldehyde containing $57.6 \mathrm{~g} / \mathrm{l}$ sucrose. The brain and the spinal cord up to C3 were removed, stored in 10, 20, and 30\% sucrose, shock-frozen in isopentane, and stored at $-70^{\circ} \mathrm{C}$ until use.

Three alternate series of $40 \mu \mathrm{m}$ thick frontal sections were cut at a cryostat (Microm HM $500 \mathrm{OM}$ ) and used for fluorescence microscopy and cytoarchitecture. Sections were analyzed at a fluorescence microscope (ZEISS Axioskop) coupled to a computer based reconstruction system (Neurolucida, MicroBrightfields). Retrogradely labeled cells with neighboring labeled fibers and terminals were additionally scanned at a confocal microscope (LSM 510 Meta, ZEISS). Photomicrographs of labeled terminals (green) and neurons (red) were taken separately with a digital camera (AxioCam, ZEISS), and brightness and contrast were adjusted and noise suppressed with Photoshop (Adobe Vs. 5.5). Finally, the pictures were superimposed with ImageJ.

\section{RESULTS}

\section{VIRAL PROPAGATION}

In order to determine the velocity of the viral propagation, in a first set of experiments we varied the survival time of the animals after injection of the shoulder muscles $(\mathrm{m}$. rhomboideus, m. trapezius). In 4 out of 8 animals the inoculation was successful, i.e., we detected retrogradely labeled cells in the brainstem, the SC and, in two cases, the motor cortex. Figure 2 shows examples of transsynaptically retrogradely labeled neurons in the midbrain of rat SC2 (see inset Figure 4). Based on the brightness of the fluorescent label we qualitatively distinguished

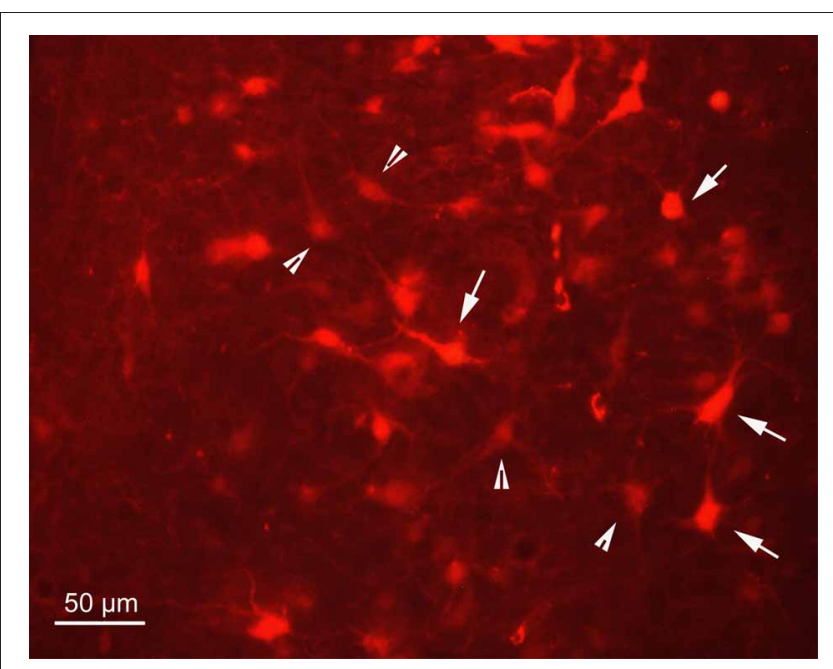

FIGURE 2 | Fluorescence photomicrograph demonstrating strongly labeled neurons (arrows) and less strongly labeled neurons (arrowheads) in the dorsal periaqueductal gray of rat SC2. The neurons were transsynaptically labeled after PrV Bartha injection into the $\mathrm{m}$. rhomboideus after a survival time of $100.5 \mathrm{~h}$. Scale bar represents $50 \mu \mathrm{m}$. 
between strongly labeled neurons (arrows in Figure 2) and weaker labeled cells (arrowheads in Figure 2). The extent of the labeling depended on the survival time. After $80-82 \mathrm{~h}$, numerous labeled neurons were observed in the reticular formation, the raphe nucleus, and the periaqueductal gray. Sparse if any labeling was present in the SC and the preoptic area (SC1, Figure 3). In Figure 3 and the following figures blue symbols indicate strongly labeled neurons, green symbols represent qualitatively weaker labeled neurons. No label was observed in the motor cortex. After 98-101 h, a high density of labeled cells was observed in the reticular formation, the raphe nucleus, and the periaqueductal gray. Now, also the intermediate and deep layers of the SC as well as the preoptic area contained considerable numbers of retrogradely labeled cells (SC2, Figure 4). Labeled neurons were now also found in the frontal and cingulate cortex (Figure 5). These data indicate that, first, about $80 \mathrm{~h}$ after inoculation the first synapse of the tectofugal projection neurons had not been transgressed, and second that $16-18 \mathrm{~h}$ later
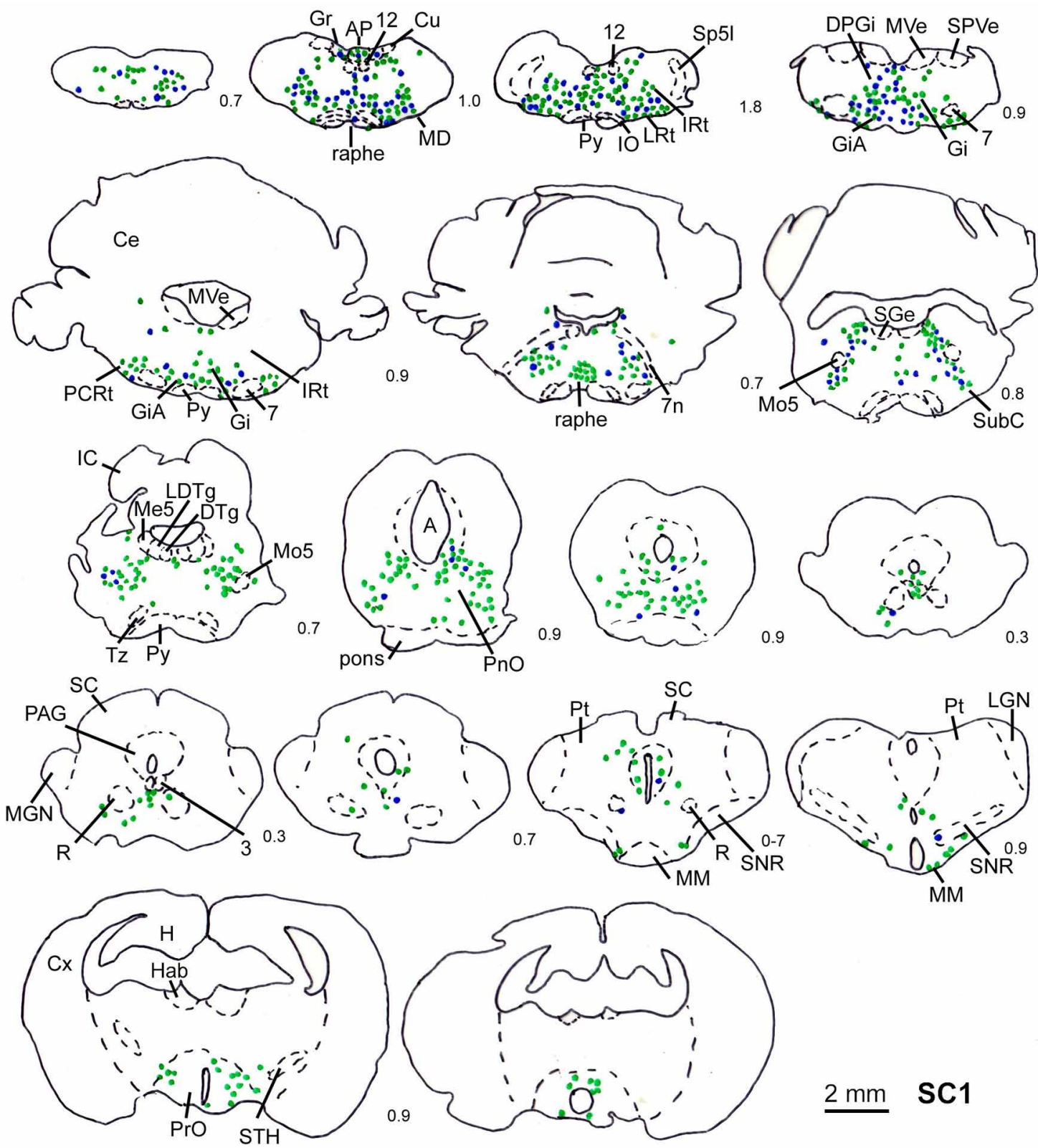

FIGURE 3 | Series of frontal sections through the brainstem and midbrain of rat SC1 demonstrating retrogradely labeled neurons after inoculation of the $\mathbf{m}$. trapezius after a survival time of $\mathbf{8 0 . 3} \mathbf{h}$. The sections are arranged from posterior (upper left) to anterior (lower right), the intersection distance in $\mathrm{mm}$ is indicated by the numbers between the sections. Blue symbols indicate strongly labeled neurons, green symbols indicate less strongly labeled cells. Scale bar indicates $2 \mathrm{~mm}$. For abbreviations see list. 

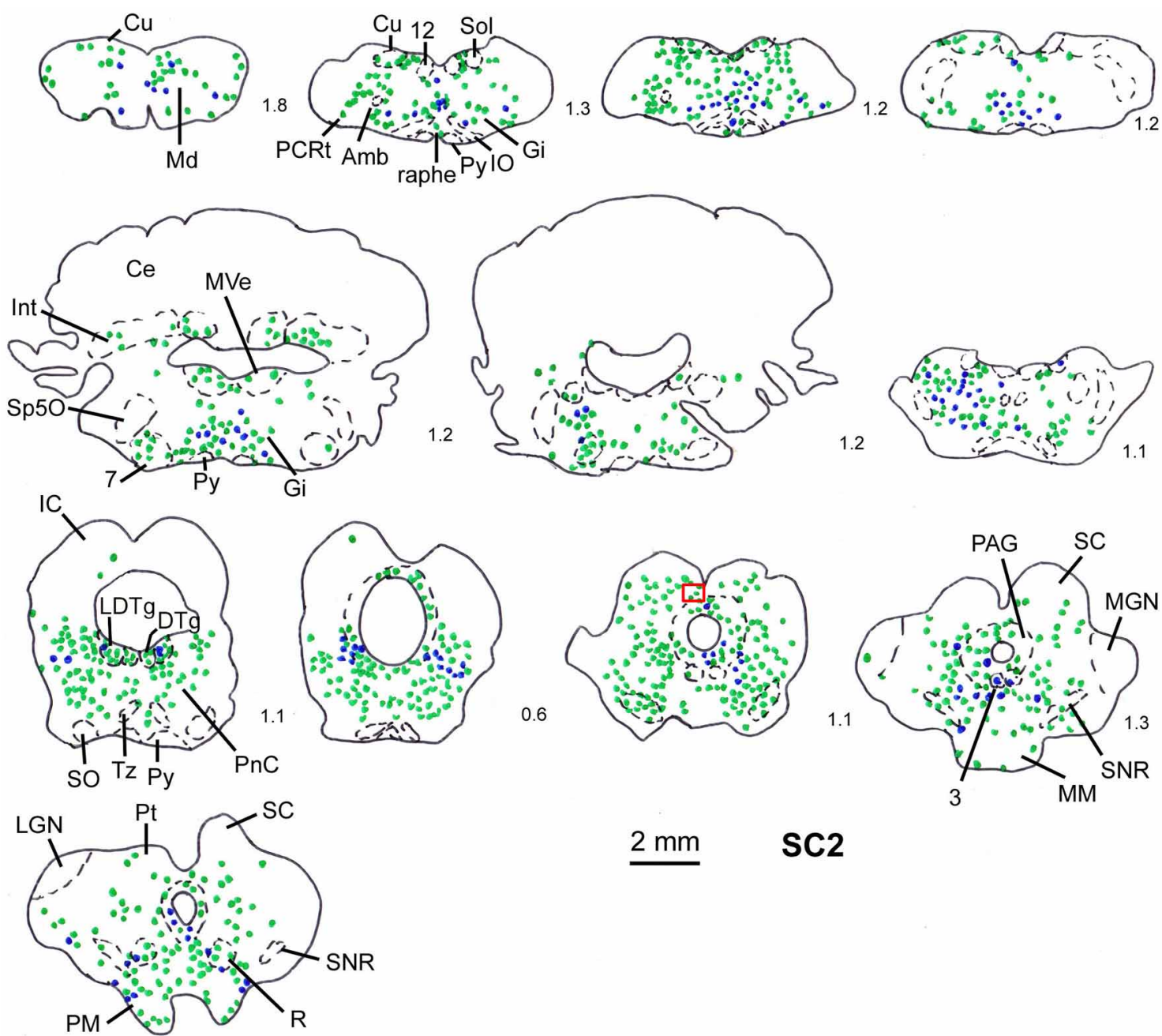

$2 \mathrm{~mm}$

SC2

FIGURE 4 | Series of frontal sections through the brainstem and midbrain of rat SC2 demonstrating retrogradely labeled neurons after virus injection into the $\mathrm{m}$. rhomboideus after a survival time of $100.5 \mathrm{~h}$. The red inset indicates the region where the photomicrograph depicted in Figure $\mathbf{1}$ was taken. Conventions as in Figure 3 a further retrograde level of the neuronal circuitry innervating skeletal muscles was labeled (i.e., the neurons projecting to the premotor neurons that project to the spinal interneurons or motoneurons).

\section{ORTHODROMIC STIMULATION}

In two cases (SC14, SC16) we used orthodromic electrical stimulation in the SC and recording of the EMG of the contralateral $\mathrm{m}$. acromiodeltoideus to determine the location of tectospinal neurons. In SC14 we employed single pulses $0.15 \mathrm{~ms}$ wide at $0.1-1.2 \mathrm{~mA}$. At a depth of $1500 \mu \mathrm{m}$ below the SC surface the highest amplitude of the EMG was recorded with a latency of $5 \mathrm{~ms}$. In SC16 we used pulse trains $(166,330 \mathrm{~Hz} ; 100 \mu \mathrm{A} ; 200 \mathrm{~ms}$ duration). At a depth of $1000 \mu \mathrm{m}$ below the SC surface, electrical stimulation caused movement of the whiskers. At a depth of $1250 \mu \mathrm{m}$ movement of the contralateral front paw was observed. The strongest effect of electrical stimulation, i.e., spreading of the contralateral paw was elicited by stimulation at $2000 \mu \mathrm{m}$ below the SC surface. These qualitative observations guided our approach for our anatomical experiments in which we made injections of FITC dextrane mainly into the deep layers of the SC to anterogradely label the projections into the brainstem. These locations yielded on average the highest frequency of varicosities in and close to nuclei containing the premotor neurons labeled after forelimb muscle injections.

\section{DUAL TRACER EXPERIMENTS}

For the dual tracer experiments we chose survival times of $73-79 \mathrm{~h}$ after which no or only few retrogradely labeled neurons were observed in the SC in our initial experiments (see above) indicating that with these survival times the first tectofugal synapse was not overcome by the retrograde propagation of the virus. In this set of experiments we inoculated both the $\mathrm{m}$. rhomboideus and/or the $\mathrm{m}$. acromiodeltoideus (Table 1). Figure 6 demonstrates examples of premotor neurons retrogradely labeled by virus inoculation of 


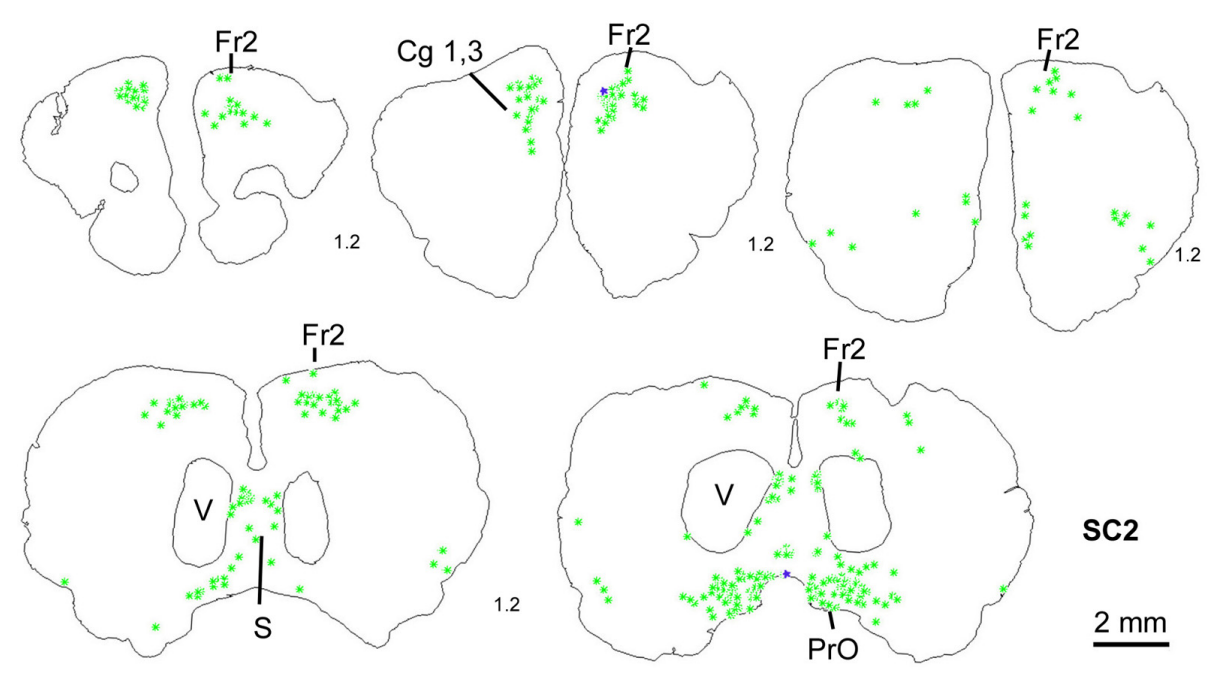

FIGURE 5 | Series of frontal sections through the frontal cortex of rat SC2 demonstrating retrogradely labeled neurons in frontal cortex after inoculation of the $\mathrm{m}$. rhomboideus after a survival time of $100.5 \mathrm{~h}$. Conventions as in Figure 3.

Table 1 | Summarized location of labeled neurons with neighboring varicosities ipsi- and contralateral to the $\mathrm{SC}$ injection site.

\begin{tabular}{|c|c|c|c|c|c|c|}
\hline \multirow[t]{2}{*}{ Area } & \multicolumn{2}{|c|}{$\begin{array}{l}\text { Superficial-intermediate } \\
\text { layers (cases SC3, } \\
\text { SC4, SC8) }\end{array}$} & \multicolumn{2}{|c|}{$\begin{array}{l}\text { Intermediate-deep } \\
\text { layers (cases SC10, } \\
\text { SC11, SC14, SC16) }\end{array}$} & \multicolumn{2}{|c|}{$\begin{array}{l}\text { Deep layers } \\
\text { (cases SC13, } \\
\text { SC15) }\end{array}$} \\
\hline & ipsi & contra & ipsi & contra & ipsi & contra \\
\hline $\mathrm{Gi}$ & 3 & 6 & 9 & 4 & 6 & 1 \\
\hline GiA & - & - & 15 & 8 & 3 & 3 \\
\hline GiV & 2 & - & 5 & - & 6 & 4 \\
\hline IRt & 1 & 3 & 7 & - & - & - \\
\hline LRt & - & - & 2 & - & 2 & - \\
\hline PCRtA & - & - & - & 1 & - & - \\
\hline $\mathrm{MdD}$ & - & 1 & - & - & 1 & - \\
\hline MdV & 1 & - & 3 & 1 & 1 & 1 \\
\hline PMn & - & - & 2 & - & 2 & 5 \\
\hline $\mathrm{PnC}$ & - & - & 11 & 5 & 4 & 3 \\
\hline $\mathrm{PnO}$ & - & - & 3 & - & - & 3 \\
\hline PnV & - & - & 4 & 2 & 1 & - \\
\hline LPGi & - & 1 & 2 & 3 & - & - \\
\hline DPGi & - & 1 & - & - & - & - \\
\hline N. raphe & 1 & & 12 & & 7 & \\
\hline DMTg & - & - & 1 & 1 & - & - \\
\hline PAG & 2 & - & - & - & - & - \\
\hline Mo5 & - & - & 1 & - & - & - \\
\hline SubC & - & - & - & 2 & 3 & - \\
\hline other & 1 & - & 3 & 4 & 6 & 2 \\
\hline
\end{tabular}

$\mathrm{m}$. rhomboideus and $\mathrm{m}$. acromiodeltoideus. In close neighborhood of these neurons fibers and varicosities anterogradely labeled from the SC can be discerned. In the various cases FITC dextrane was injected at different depths in the SC (Figure 7; Table 1).
Injections into the $m$. rhomboideus or the $m$. acromiodeltoideus and the superficial and intermediate layers of the SC.

Predominantly the superficial layers of SC were injected in 2 cases (SC3, SC4) and the superficial and intermediate layers in case SC8 (Table 1). Even though the muscles injected in these cases differed the resulting labeling was comparable. Therefore, we here only present the data of case SC4. The injection site is depicted in Figure 7A in a reconstruction of the dorsal view of the SC (left), in a section through the center of the injection (middle), as well as in a photomicrograph (right). Red outlines indicate the FITC injection site. The resulting labeling is demonstrated in the frontal sections shown in Figure 8. The majority of cells labeled by muscle inoculation were located in the nuclei of the reticular formation, i.e., in the ventral medullary reticular nucleus (MdV), the paramedian reticular nucleus (PMn), and the gigantocellular reticular nucleus (Gi). Fewer neurons were labeled in the lateral (LRt) and the intermedial reticular nucleus (IRt), the lateral paragigantocellular nucleus (LPGi), and in the raphe nucleus. Sparse labeling was found in the dorsal medullary (MdD) and the parvocellular reticular nucleus (PCRt), the dorsomedial tegmental area (DMTg), the vestibular nuclei, and the central pontine gray. Altogether, 11 neurons with adjacent fibers and varicosities labeled from the SC were found in this case, most of which were located in Gi $(n=7)$, as well as in IRt $(n=1), \operatorname{MdD}(n=1)$, $\operatorname{MdV}(n=1)$, and DPGi $(n=1)$.

The location of labeled neurons with neighboring varicosities found in cases SC3, SC4, and SC8 is summarized in Table 1.

\section{Injections into the $\mathrm{m}$. acromiodeltoideus or both $m$. acromiodeltoideus and $\boldsymbol{m}$. rhomboideus and the intermediate and deep layers of the SC}

In 4 more cases (SC10, SC11, SC14, SC16) the tracer injections encompassed the intermediate and deep layers of the SC. In case SC10 and SC11, retrograde labeling from the acromiodeltoid was rather sparse with most cells again being found in 

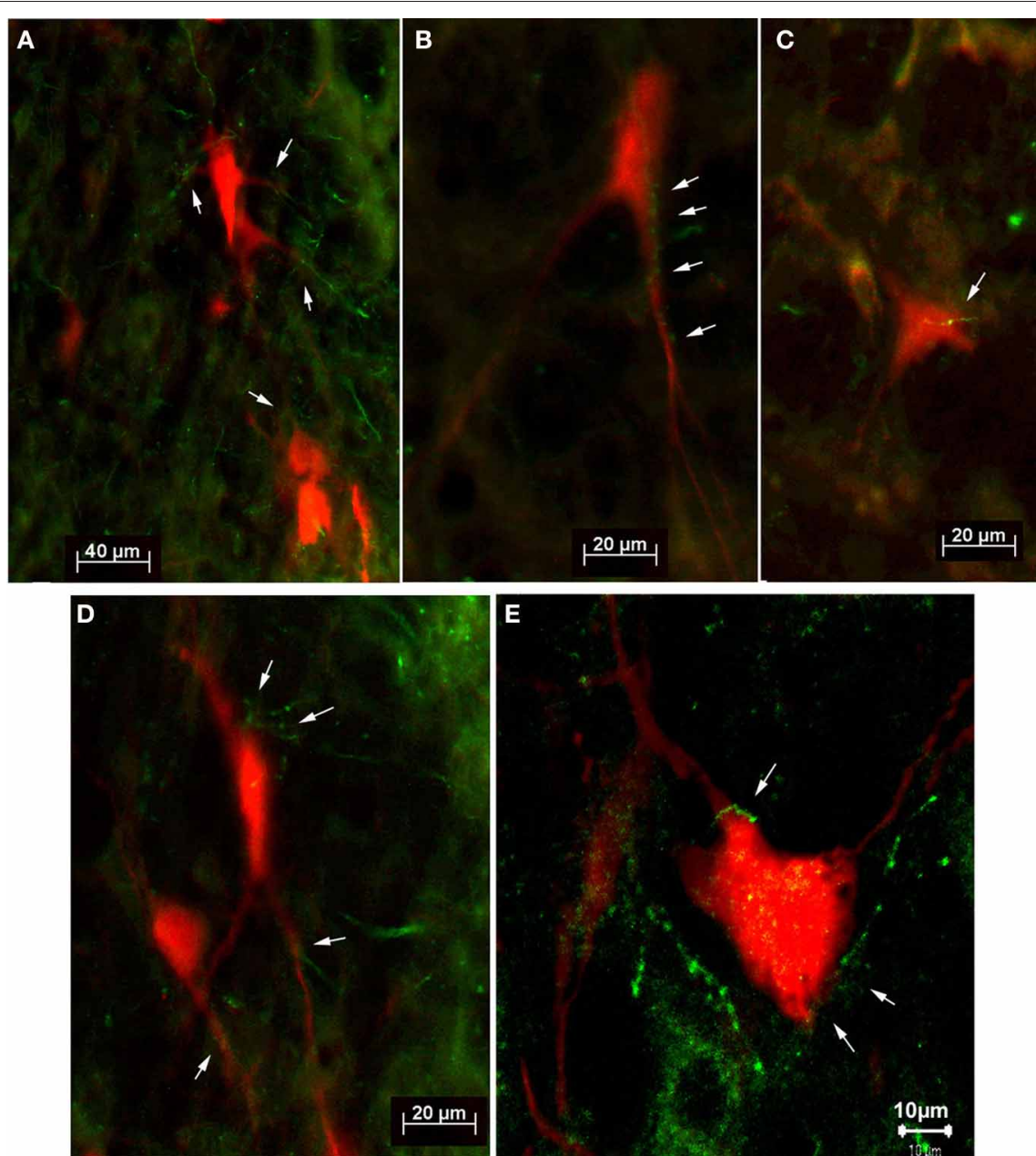

FIGURE 6 | Fluorescence photomicrographs (A-D) and confocal micrograph (E) of retrogradely labeled neurons (red) with adjacent tectofugal fibers and varicosities (green) from case SC14 (A,B,D,E) and from case SC16 (C). The neurons were located in the $n$. reticularis gigantocellularis $(\mathrm{Gi})(\mathbf{B}, \mathbf{D})$, in the $\mathrm{n}$. reticularis gigantocellularis alpha (GiA) (A,E), and in the $n$. reticularis intermedialis (C), respectively. Arrows point to anterogradely labeled tectofugal fibers with varicosities.
$\mathrm{Gi}$, the ventral and the alpha subnucleus of $\mathrm{Gi}$ ( $\mathrm{GiV}, \mathrm{GiA}$ ), and the LRt. A total of 15 neurons with neighboring varicosities were present in the reticular formation (Gi, GiA, GiV, IRt, LRt) and the DMTg. Significantly denser labeling was achieved by simultaneous inoculation of the $\mathrm{m}$. rhomboideus and $\mathrm{m}$. acromiodeltoideus in case SC14 and SC16. The tracer injection into the SC of case SC14 is demonstrated in Figure 7B, the resulting labeling is depicted in the frontal sections shown in Figure 9. Case SC14 yielded the strongest labeling of our experimental series, the distribution of the label, however, strongly resembled the other cases. Retrogradely labeled neurons were found mainly in the Gi, GiA, and GiV, with a few scattered neurons outside the reticular formation. The intracollicular tracer injection anterogradely labeled terminal fields in the ipsilateral GiA and the ipsilateral $\mathrm{PnC} / \mathrm{PnO}$ as well as a smaller terminal field in the contralateral PnO. Altogether, 65 neurons with neighboring varicosities were found, 51 of which were located in the reticular formation. Most of these neurons lie in the GiA, the PnC, the $\mathrm{PnO}, \mathrm{Gi}$, and MdV. In addition, neurons with varicosities were found in the n. raphe, isolated neurons lay in the facial and the trigeminal nucleus, the DMTg, and the n. subcoeruleus. The SC injection in case SC16 confirmed the results from SC14. The data of the injections into the intermediate-deep collicular layers are summarized in Table $\mathbf{1 .}$

\section{Injections into both the m.acromiodeltoideus and the m. rhomboideus and into the deep layers of the SC}

In two animals (SC13, SC15), the tracer injections were restricted to the deep layers of the SC. These injections were combined with inoculation of both the m. rhomboideus and the m. acromiodeltoideus. Even though the resulting amount of labeled neurons was much higher in SC13 than in SC15, the distribution of the cells was very similar. We therefore demonstrate only case SC13 (Figures 7C, 10). Again, the majority of labeled neurons lay in $\mathrm{Gi}$, $\mathrm{GiA}, \mathrm{GiV}$, and the raphe nucleus, with additional cells in DPGi, $\mathrm{PnV}$, and $\mathrm{PnD}$. The SC injection resulted in labeling of distinct terminal fields in the ipsilateral GiA and PnC/PnV. A total of 32 retrogradely labeled neurons with neighboring varicosities were identified, 26 of which were located in the reticular formation, mainly in GiV, PMn, PnC, followed by Gi, GiV, MdV, PnV, the 


\section{A}

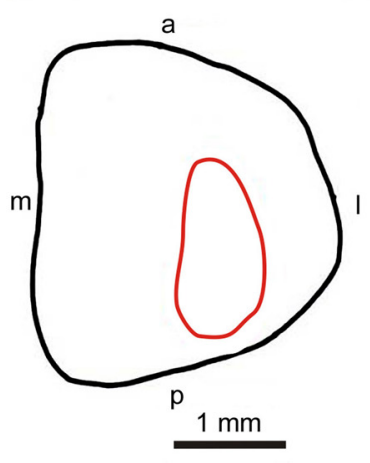

B

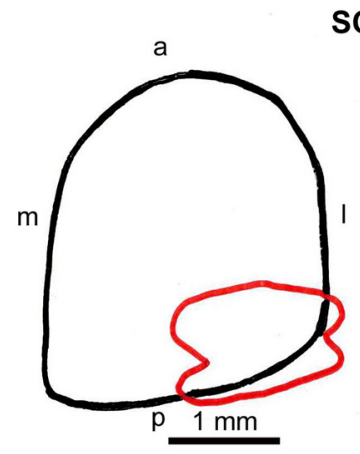

SC4

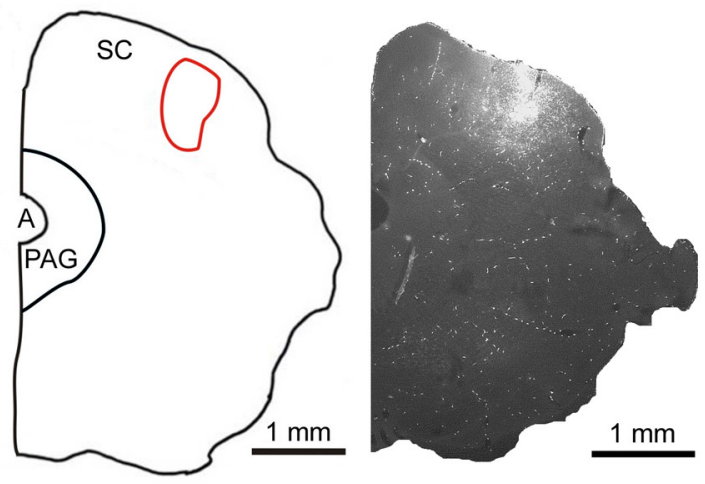

SC14
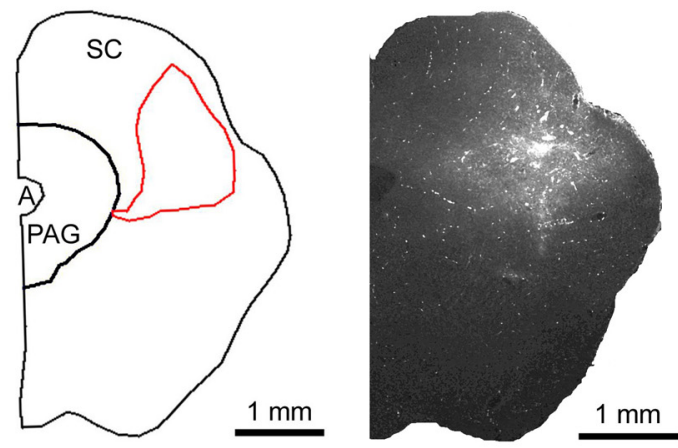

C

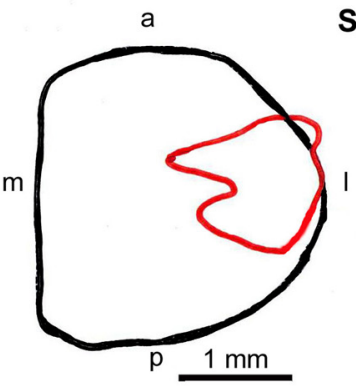

SC13
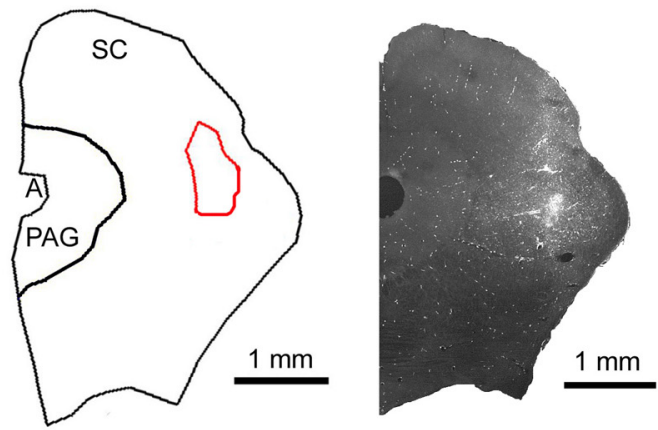

FIGURE 7 | Injection sites into the superficial (A, SC4), the intermediate-deep (B, SC14), and the deep (C, SC13) layers of the superior colliculus. Left panel: reconstructions of the dorsal view of the right SC, middle panel: drawings of frontal sections through the center of the injection sites, right panel: fluorescent photomicrographs of the FITC injection sites. Red outlines in the left and middle row indicate the location of the FITC injections into the SC. a, anterior; p, posterior; I, lateral; m, medial; scale bars indicate $1 \mathrm{~mm}$. raphe nucleus, and the n. subcoeruleus. The results of cases SC13 and SC15 are summarized in Table $\mathbf{1 .}$

Comparing all cases, two observations become apparent. First, the neurons projecting to the skeletomuscular system of the forelimb and potentially receiving input from the SC are mainly located in the various nuclei of the reticular formation and the raphe nucleus. Their distribution is ipsilaterally biased (104 ipsivs. 59 contralateral; $p<0.02$ in a $\chi^{2}$-test). Second, SC injections into the deep layers on average yield stronger brain stem projections than injections into the intermediate/deep or the superficial/intermediate layers.

\section{DISCUSSION}

There are at least three disynaptic pathways from the deep layers of the SC to the motoneurons innervating the muscles of the shoulder and forelimb: first, the tectospinal projection via interneurons in the cervical enlargement; second, the tectospinal projection via propriospinal neurons in segments $\mathrm{C} 3-\mathrm{C} 4$, and third, the tecto-reticulo-spinal projection. In the present study we directly demonstrate for the first time the relay stations of the tecto-reticulo-spinal pathway to the skeletomotor system in the rat by simultaneously labeling tectal efferents with an anterogradely transported tracer, and the premotor neurons to the 

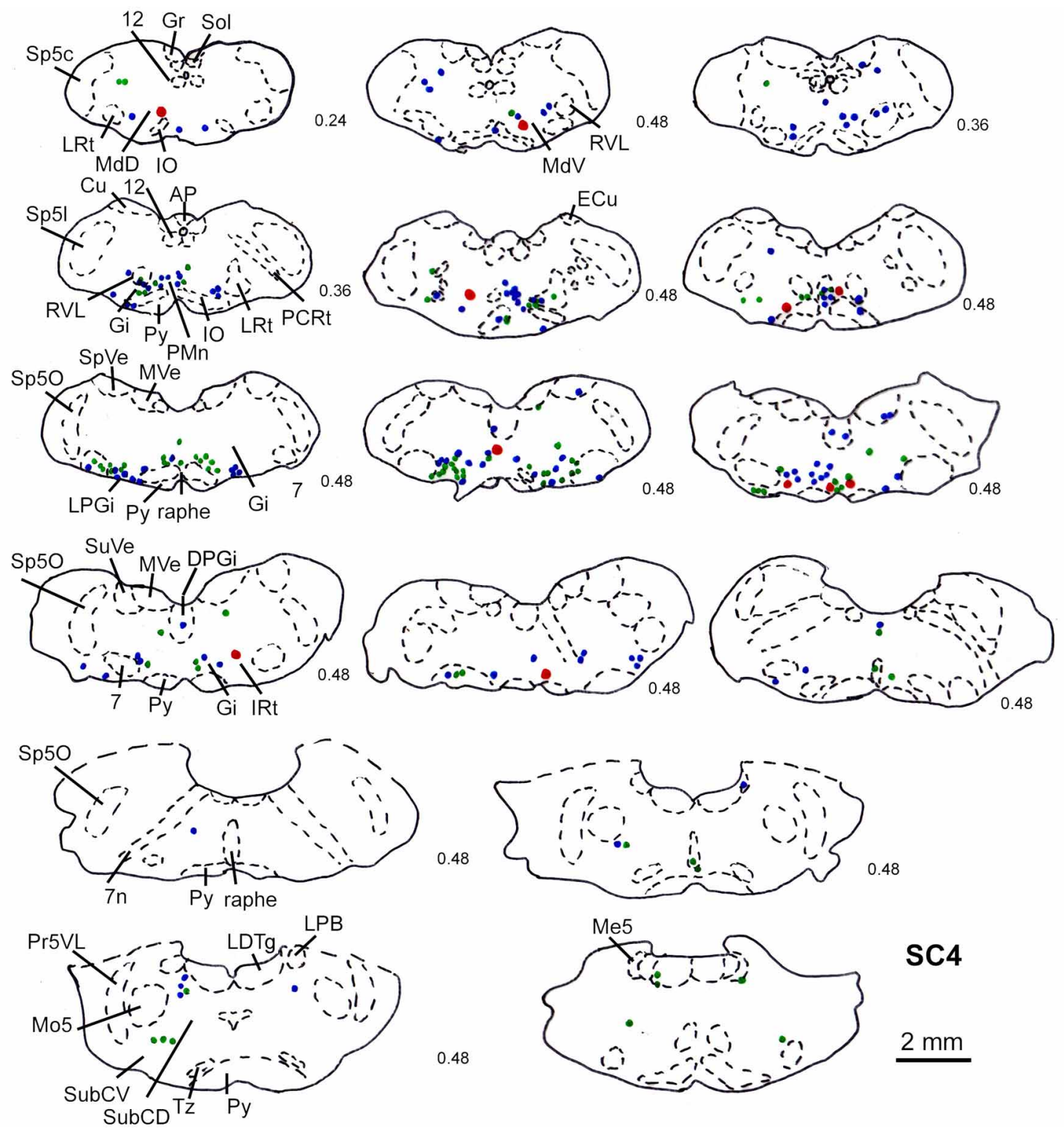

Sc4

0.48

FIGURE 8 | Series of frontal sections through the brainstem and midbrain of case SC4 demarcating the location of retrogradely labeled neurons after inoculation of the left $\mathrm{m}$. acromiodeltoideus (survival time of $79 \mathrm{~h}$ after inoculation) and FITC labeled varicosities after injection into the superficial layers of the right SC ( 2 days before the muscle inoculation). Red symbols indicate retrogradely labeled cells with adjacent tectofugal fibers and varicosities. Other conventions as in Figure $\mathbf{3}$. shoulder and arm muscles by inoculation with the transsynaptic retrograde tracer PrV Bartha. Retrogradely labeled neurons with adjacent tectofugal fibers and varicosities, i.e., presumed terminals were predominantly located in the reticular formation, mainly in the gigantocellular nuclear complex, and the raphe nucleus indicating an at least trisynaptic innervation of the shoulder muscles.

\section{METHODOLOGICAL CONSIDERATIONS}

In our experiments we used the attenuated alpha-herpes virus PrV Bartha that has been used in various systems including the locomotor system (Jovanovic et al., 2010). Pseudorabies virus supposedly has several disadvantages compared to rabies virus including infection of glia and epithelial cells, sensory and motor neurons, neuronal degeneration, and local spread (Ugolini, 2010). We chose an attenuated virus stock with high titer $\left(10^{8} \mathrm{pfu} / \mathrm{ml}\right)$ to maximize the transneuronal transfer, and placed the inoculation close to or in the nerves supplying the various muscles therefore minimizing unspecific spread. To really limit the retrograde viral propagation to two synapses the strategy of genomic deletion of the gene encoding a glycoprotein (Gly) essential for transsynaptic spread should have been applied (Callaway, 2008; Arber, 2012). 
Sp5C Sol AP Gr Cu
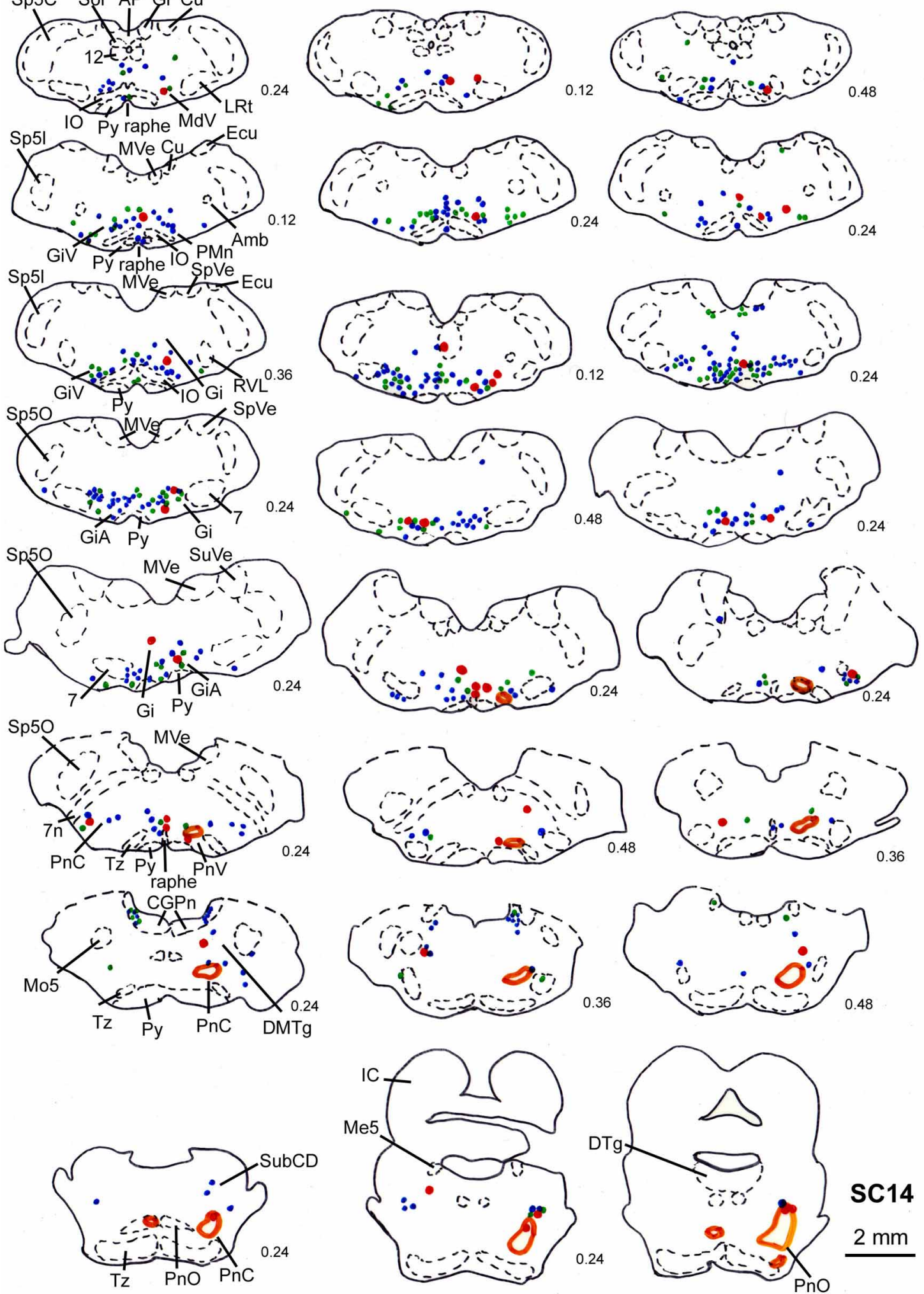

FIGURE 9 | Series of frontal sections through the brainstem and midbrain of case SC14 showing retrogradely labeled neurons after virus injection into the left $\mathbf{m}$. acromiodeltoideus and the left $\mathbf{m}$. rhomboideus, and FITC injection into the intermediate and deep layers of the right SC after a survival time of $\mathbf{7 3} \mathrm{h}$ after inoculation. Orange outlines indicate dense tectofugal terminal fields. Conventions as in Figures $\mathbf{3}, \mathbf{8}$ 

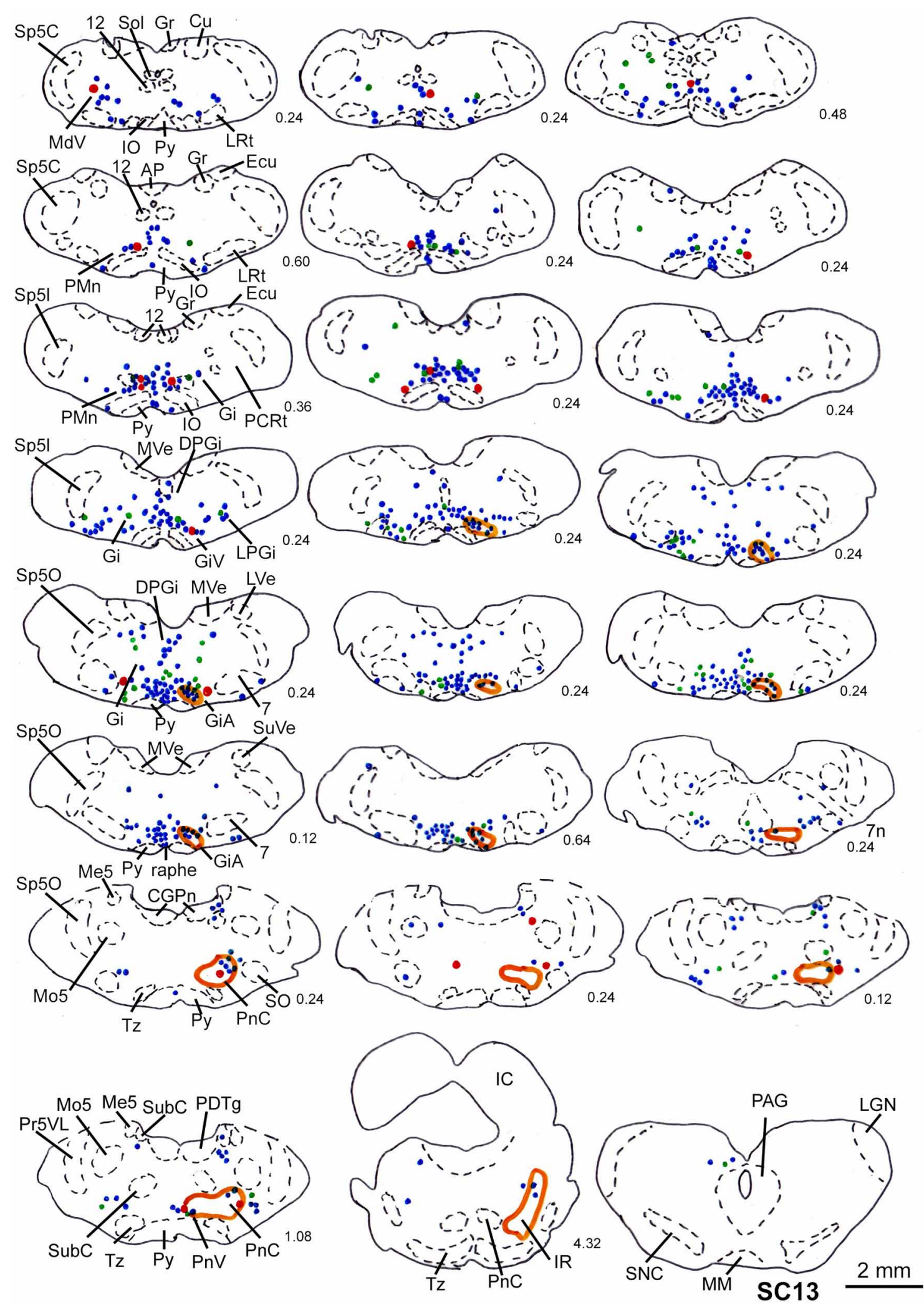

FIGURE 10 | Series of frontal sections through the brainstem and midbrain of case $\mathrm{SC} 13$ showing retrogradely labeled neurons after virus injection into the left $\mathbf{m}$. acromiodeltoideus and left $\mathbf{m}$. rhomboideus (survival time of $73 \mathrm{~h}$ after inoculation), and FITC labeled varicosities after injection into the deep layers of the right SC. Orange outlines indicate dense tectofugal terminal fields. Conventions as in Figures 3, 8 . 
Degenerating virus-labeled cells were mainly found in our prior experiments after long survival times $(>100 \mathrm{~h})$ but were much less numerous with survival times around $80 \mathrm{~h}$ (data not shown). In our dual tracing experiments labeled tectofugal terminals were found adjacent to putatively intact neurons. The resulting retrograde labeling in the brainstem differed quantitatively but was qualitatively very similar in all cases thereby justifying the use of PrV Bartha in our tracing system. The reported amount of labeled cells with adjacent tectofugal varicosities probably is an underestimate because of two reasons. First, using an mRFP1 labeled virus strain in combination with an anterograde tracer coupled to the fluorescent dye FITC allowed us to directly view the resulting label. However, fading of the fluorescence limited viewing time. Thus, mainly strongly labeled cells and varicosities were detected. Second, the retrograde label was usually limited to the soma and proximal dendrites of the cells. As most axon terminals contact the dendrites of their target cells, these contacts remained undetected. Nevertheless, the constancy of the label across cases indicates that our results are highly reproducible.

\section{COMPARISON WITH OTHER STUDIES}

Our dual tracing results are in accordance with electrophysiological studies. Electrical stimulation of the SC activates spinal motoneurons and thus influences movements of the limbs (e.g., Anderson et al., 1972; Sinnamon, 1984; Courjon et al., 2004; Philipp and Hoffmann, unpublished observation) and the neck (e.g., Anderson et al., 1971). This influence seems to be mediated by the reticular formation that receives input from the SC (Peterson et al., 1971) and in turn projects to the motoneurons supplying muscles of the neck, back, fore- and hindlimbs (Peterson et al., 1979). Especially neurons in the n. reticularis pontis caudalis and in the dorsorostral part of the gigantocellular reticular nucleus monosynaptically innervate motoneurons of the axial and limb musculature. Neurons in the pontomedullary reticular formation are modulated during limb movements (Buford and Davidson, 2004; Schepens and Drew, 2004; Schepens et al., 2008), and micro-stimulation in this region elicits muscle activity in the limbs as well as head movements and influences gaze shifts (Drew and Rossignol, 1990a,b; Freedman and Quessy, 2004; Quessy and Freedman, 2004; Davidson and Buford, 2006). A tecto-reticulo-spinal pathway for head orienting movements was also described anatomically (Perkins et al., 2009). A recent study in mouse implicates the precuneiform nucleus in the mesencephalic locomotor region in the generation of limb movements (Liang et al., 2012). However, in none of our dual tracer cases did we find neurons retrogradely labeled from the shoulder muscles with adjacent tectal projections in this region indicating that the precuneiform nucleus is not part of the shortest tectofugal pathway supplying shoulder muscles.

Our successful SC-injection sites were located in the lateral part of the SC where in primates reach-related activity can be recorded in the intermediate and deep layers (Werner, 1993; Werner et al., 1997a,b) and where microstimulation elicits arm movements (Philipp and Hoffmann, unpublished observation). These injections labeled circumscribed fields with dense terminals mainly if not exclusively ipsilaterally in the GiA and the PnC confirming data by Kawamura et al. (1974) and Redgrave et al.
(1990). Relatively few neurons retrogradely labeled from the forelimb muscles were detected within these terminal fields, most neurons with adjacent terminals were found in other regions of the GiA and $\mathrm{PnC}$ which only showed a moderate ipsilateral bias.

\section{TECTO-SPINAL OR TECTO-RETICULO-SPINAL CONNECTION?}

Transneuronal labeling with viruses allows visualization of not only first-order, but also second- and third-order neurons with comparable labeling strength because viruses replicate after infecting new neurons after crossing synapses (Ugolini, 1995). This property also indicates that the velocity of the transneuronal propagation in a system depends on the number of synapses crossed. In our first series of experiments we varied survival time between 80 and $100 \mathrm{~h}$ after inoculation. With shorter survival times $(80 \mathrm{~h})$ retrogradely labeled neurons were mainly present in the reticular formation and in the raphe nucleus but neither in SC nor in the cerebral cortex. After longer survival labeled neurons were also present in the SC and the frontal and cingulate cortex indicating that at least one additional synapse had been crossed. In a recent study in neonatal mice the time course of transsynaptic propagation of PrV Bartha after inoculation of hindlimb muscles was investigated in detail (Jovanovic et al., 2010). Motoneurons in the lumbar spinal cord were labeled after 24-32 h, interneurons projecting monosynaptically to the motoneurons were encountered after 36-40 $\mathrm{h}$ indicating that the transsynaptic propagation over one synapse takes about $12 \mathrm{~h}$. Infection and propagation time varies with age and species (Ugolini, 1995). In young adult rats, premotoneuronal cells were labeled after 52-72 h after inoculation of various muscles and the sciatic nerve (e.g., Dobbins and Feldman, 1994, 1995; Kim et al., 2000; Chamberlin et al., 2007). This indicates that with our survival times of $72-82 \mathrm{~h}$ the labeled neurons in the reticular formation are indeed premotoneurons, also considering the fact that viral replication may vary between injections into the periphery (i.e., the muscles) and into the nervous system.

Our data confirm earlier data that in rat direct corticomotoneuronal connections are not established (e.g., Yang and Lemon, 2003; Alstermark et al., 2004). With survival times of $72-79 \mathrm{~h}$ we did not find retrogradely labeled neurons in the SC. This clearly demonstrates that the tecto-motoneuronal projection in rat is subtle at best. In contrast, our experiments clearly support a robust tecto-spinal and tecto-reticulo-spinal pathway with at least 3 synapses between SC and forelimb muscles. In the tecto-reticulo-spinal pathway most retrogradely labeled neurons with adjacent FITC labeled varicosities that presumably represent input from the SC were located in the gigantocellular complex of the reticular formation as well as in PnC.

\section{FUNCTIONAL CONSIDERATIONS}

In rodents, there appears to exist a functional segregation of the SC, with the medial SC and its representation of the dorsal visual field being responsible for detection of putative predators, and the lateral SC representing the horizontal and ventral visual field being assigned to the detection of possible prey and social partners (Dean et al., 1989). In line with this hypothesis, Comoli and coworkers could demonstrate in a recent study (Comoli et al., 2012) that the defense region in the medial SC 
and the approach-related region in the lateral SC receive distinct cortical and subcortical afferents with very little overlap between the two regions. Using electrical stimulation, Sahibzada and colleagues found that contralateral orienting and approach behavior could be elicited mainly from the intermediate and deep layers of the rostral and central SC and from all layers but the deep white in caudal SC. By contrast, mainly ipsilateral avoidance and defense behavior was seen after stimulation of the superficial and intermediate layers of the rostral SC, the intermediate and deep layers of central SC, and the deep layers of the caudal SC (Sahibzada et al., 1986). Comparing their results with anatomical and lesion evidence the authors suggest that orientation and approach movements are mediated via the crossed tectofugal pathway whereas avoidance involves the ipsilateral tectofugal projections. In this respect, rodents may well differ from e.g., primates or carnivores due to the quite different predator-prey ecology.

Our present experiments show that premotoneuronal neurons in the reticular formation transsynaptically labeled from the shoulder muscles receiving tectofugal afferents are more often found ipsilaterally to the injected SC than contralaterally. This could imply that this pathway is more involved in avoidance than in appetitive behavior indicated by reaching. Nevertheless, our

\section{REFERENCES}

Akert, K. (1949). The visual grasp reflex. Helv. Physiol. Acta 7, $112-134$.

Alstermark, B., and Isa, T. (2012). Circuits for skilled reaching and grasping. Annu. Rev. Neurosci. 35, 559-578. doi: 10.1146/annurevneuro-062111-150527

Alstermark, B., Isa, T., Pettersson, L. G., and Sasaki, S. (2007). The C3C4 propriospinal system in the cat and monkey: a spinal premotoneuronal centre for voluntary motor control. Acta Physiol. (Oxf). 189, 123-140. doi: 10.1111/j.17481716.2006.01655.x

Alstermark, B., Ogawa, J., and Isa, T. (2004). Lack of monosynaptic corticomotoneural EPSPs in rats: disynaptic EPSPs mediated via reticulospinal neurons and polysynaptic EPSPs via segmental interneurons. J. Neurophysiol. 91, 1832-1839. doi: 10.1152/jn.00820.2003

Anderson, M. E., Yoshida, M., and Wilson, V. J. (1971). Influence of superior colliculus on cat neck motoneurons. J. Neurophysiol. 34, 898-907.

Anderson, M. E., Yoshida, M., and Wilson, V. J. (1972). Tectal and tegmental influences on cat forelimb and hindlimb motoneurons. J. Neurophysiol. 35, 462-470.

Arber, S. (2012). Motor circuits in action: specification, connectivity, and function. Neuron 74, 975-969. doi: 10.1016/j.neuron.2012.05.011
Banfield, B. W., Kaufmann, J. D., Randall, J. A., and Pickard, G. E. (2003). Development of pseudorabies virus strains expressing red fluorescent proteins: new tools for multisynaptic labelling applications. J. Virol. 77, 10106-10112. doi: $\quad$ 10.1128/JVI.77.18.1010610112.2003

Barton, R. A., and Dean, P. (1993). Comparative evidence indicating neural specialization for predatory behaviour in mammals. Proc. Biol. Sci. 254, 63-68. doi: 10.1098/rspb.1993.0127

Buford, J. A., and Davidson, A. G. (2004). Movement-related and preparatory activity in the reticulospinal system of the monkey. Exp. Brain Res. 159, 284-300. doi: 10.1007/s00221-004-1956-4

Callaway, E. M. (2008). Transneuronal rotropic viruses. Curr. Opin. Neurobiol. 18, 617-623. doi: 10.1016/j.conb.2009.03.007

Chamberlin, N. L., Eikermann, M., Fassbender, P., White, D. P., and Malhotra, A. (2007). Genioglossus premotoneurons and the negative pressure reflex in rats. J. Physiol. 579, 515-526. doi: 10.1113/jphysiol.2006.121889

Comoli, E., Das Neves Favaro, P., Vautrelle, N., Leriche, M., Overton, P. G., and Redgrave, P. (2012). Segregated anatomical input to subregions of the rodent superior colliculus associated with approach circuit tracing with neu-

SC injections were always placed in the lateral SC with receptive fields below the horizon that are suited to register food or conspecifics. Interestingly, most neurons connecting the SC to motoneurons of forelimb muscles were found in the nucleus gigantocellularis. In a recent paper, Pfaff et al. (2012) describe the importance of neurons in this nucleus which may have originated from the Mauthner cells in fish for general arousal in mammals. Our data do not allow us to decide about the exact function of the projections revealed in the present study but the bilateral, (though ipsilaterally biased) projection suggests a more global function in motivated behavior like preparing for action or sensory-guided locomotor decisions (Felsen and Mainen, 2008). Further experiments with electrical stimulation or, better still, applying optogenetic methods to lateral vs. medial regions of the SC in behaving animals could help to elucidate this matter.

\section{ACKNOWLEDGMENTS}

We thank H. Hatt for providing access to the biosafety level 2 lab and the confocal microscope, $\mathrm{H}$. Korbmacher for providing microelectrodes and pipettes, and S. Krämer for technical help. We are also very grateful to B. G. Klupp and T. C. Mettenleiter for providing the $\operatorname{PrV}$ construct. This study was supported by a ZEN grant of the Hertie Foundation to K.-P. Hoffmann.

and defense. Front. Neuroanat. 6:9. doi: 10.3389/fnana.2012.00009

Courjon, J. H., Olivier, E., and Pélisson, D. (2004). Direct evidence for the contribution of the superior colliculus in the control of visually guided reaching movements in the cat. J. Physiol. 556, 675-681. doi: 10.1113/jphysiol. 2004.061713

Cuthbertson, S., LeDoux, M. S., Jones, S., Jones, J., Zhou, Q., Gong, S., et al. (2003). Localization of preganglionic neurons that innervate choroidal neurons of pterygopalatine ganglion. Invest. Ophthalmol. Vis. Sci. 44, 3713-3724. doi: 10.1167/iovs.02-1207

Damann, N., Rothermel, M., Klupp, B. G., Mettenleiter, T. C., Hatt, H., and Wetzel, C. H. (2006). Chemosensory properties of murine nasal and cutaneous trigeminal neurons identified by viral tracing. BMC Neurosci. 7:46. doi: 10.1186/1471-2202-7-46

Davidson, A. G., and Buford, J. A. (2006). Bilateral actions of the reticulospinal tract on arm and shoulder muscles in the monkey: stimulus triggered averaging. Exp. Brain Res. 173, 25-39. doi: 10.1007/s00221006-0374-1

Dean, P., Redgrave, P., and Westby, G. W. M. (1989). Event or emergency? Two response systems in the mammalian superior colliculus. Trends Neurosci. 12, 137-147. doi: 10.1016/ 0166-2236(89)90052-0
DeFalco, J., Tomishima, M., Liu, H., Zhao, C., Cai, X., Marth, J. D., et al. (2001). Virus-assisted mapping of neural inputs to a feeding center in the hypothalamus. Science 291, 2608-2613. doi: 10.1126/science. 1056602

Dobbins, E. G., and Feldman, J. L. (1994). Brainstem network controlling descending drive to phrenic motoneurons in rat. J. Comp. Neurol. 347, 64-86. doi: 10.1002/cne.903470106

Dobbins, E. G., and Feldman, J. L. (1995). Differential innervation of protruder and retractor muscles of the tongue in rat. J. Comp. Neurol. 357, 376-394. doi: 10.1002/cne.903570305

Drew, T., and Rossignol, S. (1990a). Functional organization within the medullary reticular formation of intact unanesthetized cat. I. Movements evoked by microstimulation. J. Neurophysiol. 64, 767-781.

Drew, T., and Rossignol, S. (1990b). Functional organization within the medullary reticular formation of intact unanesthetized cat. II. Electromyographic activity evoked by microstimulation. J. Neurophysiol. 64, 782-795.

Enquist, L. W. (1994). Infection of the mammalian nervous system by pseudorabies virus (PrV). Semin. Virol. 5, 221-231. doi: 10.1086/ 344278 
Enquist, L. W. (2002). Exploiting circuit-specific spread of pseudorabies virus in the central nervous system: insights to pathogenesis and circuit tracers. J. Infect. Dis. 186, 209-214. doi: 10.1086/344278

Felsen, G., and Mainen, Z. F. (2008). Neural substrates of sensory-guided locomotor decisions in the rat superior colliculus. Neuron 60, 137-148. doi: 10.1016/j.neuron. 2008.09.019

Freedman, E. G., and Quessy, S. (2004). Electrical stimulation of rhesus monkey nucleus reticularis gigantocellularis. II. Effects on metrics and kinematics of ongoing gaze shifts. Exp. Brain Res. 156, 357-376. doi: 10.1007/s00221-004-1840-2

Greene, E. (1935). "Anatomy of the rat," in Transactions of the American Philosophical Society, New Ser., Vol. 27. New York, NY: Hafner Publishing, 1-370.

Grillner, S., and Lund, S. (1968). The origin of a descending pathway with monosynaptic action on flexor motoneurons. Acta Physiol. Scand. $74,274-284$

Illert, M., Lundberg, A., Padel, Y., and Tanaka, R. (1978). Integration in descending motor pathways controlling the forelimb in the cat. 3 . Convergence on propriospinal neurons transmitting disynaptic excitation from the corticospinal tract and other descending tracts. Exp. Brain Res. 33, 101-130.

Jovanovic, K., Pastor, A. M., and O'Donovan, M. J. (2010). The use of PRV-Bartha to define premotor inputs to lumbar motoneurons in the neonatal spinal cord of the mouse. PLOS ONE 5:e11743. doi: 10.1371/journal.pone.0011743

Kawamura, K., Brodal, A., and Hoddevik, G. (1974). The projection of the superior colliculus onto the reticular formation of the brainstem. An experimental anatomical study in the cat. Exp. Brain Res. 19, 1-19.

Keay, K., Westby, G. W. M., Frankland, P., Dean, P., and Redgrave, R. (1990). Organization of the crossed tecto-reticulo-spinal projection in rat. II. Electrophysiological evidence for separate output channels to the periabducens area and caudal medulla. Neuroscience 37, 585-601. doi: 10.1016/0306-4522(90)90093-J

Kerman, I. A. (2008). Organization of brain somatomotor-sympathetic circuits. Exp. Brain Res. 187, 1-16. doi: 10.1007/s00221-008-1337-5

Kim, E. S., Li, H., McCulloch, P. F., Morrison, L. A., Yoon, K. W., and $\mathrm{Xu}, \mathrm{X} . \mathrm{M}$. (2000). Spatial and temporal patterns of transneuronal labelling in CNS neurons after injection of pseudorabies virus in the sciatic nerve of adult rats. Brain Res. 857, 41-55. doi: 10.1016/S00068993(99)02332-X

Kuypers, H. G. J. M., and Ugolini, G. (1990). Viruses as transneuronal tracers. Trends Neurosci. 13, 71-75.

Liang, H., Paxinos, G., and Watson, C. (2012). Spinal projections from the presumptive midbrain locomotor region in the mouse. Brain Struct. Funct. 217, 211-219. doi: 10.1007/s00429-011-0337-6

Marson, L., and McKenna, K. E. (1996). CNS cell groups involved in the control of the ischiocavernosus and bulbospongiosus muscles: a transneuronal tracing study using pseudorabies virus. J. Comp. Neurol. 374, 161-179. doi: 10.1002/(SICI) 1096-9861(19961014)374:2<161:: AID-CNE1 > 3.0.CO;2-0

Meredith, M. A., Miller, L. K., Ramoa, A. S., Clemo, H. R. H., and Behan, M. (2001). Organization of the neurons of origin of the descending pathways from the ferret superior colliculus. Neurosci. Res. 40, 301-313. doi: 10.1016/S0168-0102 (01)00240-1

Murray, E. A., and Coulter, J. D. (1982). Organization of tectospinal neurons in the cat and rat superior colliculus. Brain Res. 243, 201-214. doi: 10.1016/0006-8993(82)90243-8

Muto, N., Kakei, S., and Shinoda, Y. (1996). Morphology of single axons of corticospinal neurons in the upper cervical spinal cord. J. Comp. Neurol. 372, 9-26. doi: 10.1002/ (SICI)1096-9861(19960812)372:1< 9::AID-CNE2 > 3.0.CO;2-7

Nudo, R. J., and Masterton, R. B. (1988). Descending pathways to the spinal cord: a comparative study of 22 mammals. J. Comp. Neurol. 277, 53-79. doi: 10.1002/cne.902770105

Nudo, R. J., and Masterton, R. B. (1989). Descending pathways to the spinal cord: II. quantitative study of the tectospinal tract in 23 mammals. J. Comp. Neurol. 286, 96-119. doi: $10.1002 /$ cne. 902860107

Perkins, E., Warren, S., and May, P. J. (2009). The mesencephalic reticular formation as a conduit for primate collicular gaze control: tectal inputs to neurons targeting the spinal cord and medulla. Anat. Rec. 292, 1162-1181. doi: 10.1002/ ar.20935

Peterson, B. W., Anderson, M. E., Filion, M., and Wilson, V. J. (1971). Responses of reticulospinal neurons to stimulation of the superior colliculus. Brain Res. 33, 495-498. doi: 10.1016/0006-8993 (71)90124-7
Peterson, B. W., Pitts, N. G., and Fukushima, K. (1979). Reticulospinal connections with limb and axial motoneurons. Exp. Brain Res. 36, 1-20.

Pfaff, D. W., Martin, E. M., and Faber, D. (2012). Origins of arousal: roles for medullary reticular neurons. Trends Neurosci. 35, 468-476. doi: 10.1016/j.tins.2012.04.008

Pickard, G. E., Smeraski, C. A., Tomlinson, C. C., Banfield, B. W. Kaufman, J., Wilcox, C. L., et al. (2002). Intravitreal injection of the attenuated pseudorabies virus PrV Bartha results in infection of the hamster suprachiasmatic nucleus only by retrograde transsynaptic transport via autonomic circuits. J. Neurosci. 22, 2701-2710.

Quessy, S., and Freedman, E. G. (2004). Electrical stimulation of rhesus monkey nucleus reticularis gigantocellularis. I. Characteristics of evoked head movements. Exp. Brain Res. 156, 342-356. doi: 10.1007/s00221-003-1787-8

Redgrave, R., Dean, P., and Westby, G. W. M. (1990). Organization of the crossed tecto-reticulo-spinal projection in rat. I. Anatomical evidence for separate output channels to the periabducens area and caudal medulla. Neuroscience 37, 571-584. doi: 10.1016/0306-4522 (90)90092-I

Rhoades, R. W., and DellaCroce, D. R. (1980). Cells of origin of the tectospinal tract in the golden hamster: an anatomical and electrophysiological investigation. Exp. Neurol. 67, 163-180. doi: 10.1016/00144886(80)90167-3

Rose, P. K., MacDonald, J., and Abrahams, V. C. (1991). Projections of the tectospinal tract to the upper cervical spinal cord of the cat. A study with the anterograde tracer Pha-L. J. Comp. Neurol. 314, 91-105. doi: 10.1002/cne. 903140109

Sahibzada, N., Dean, P., and Redgrave, P. (1986). Movements resembling orientation and avoidance elicited by electrical stimulation of the superior colliculus in rats. J. Neurosci. 6 , 723-733.

Schäfer, K. P. (1970). Unit analysis and electrical stimulation of the optic tectum of rabbits and cats. Brain Behav. Evol. 3, 222-240.

Schepens, B., and Drew, T. (2004). Independent and convergent signals from the pontomedullary reticular formation contribute to the control of posture and movement during reaching in the cat. J. Neurophysiol. 92, 2217-2238. doi: 10.1152/jn. 01189.2003
Schepens, B., Stapley, P., and Drew, T. (2008). Neurons in the pontomedullary reticular formation signal posture and movement both as integrated behaviour and independently. J. Neurophysiol. 100, 2235-2253. doi: 10.1152/jn.01381.2007

Sinnamon, H. M. (1984). Forelimb and hindlimb stepping by the anesthetized rat elicited by electrical stimulation of the diencephalon and mesencephalon. Physiol. Behav. 33, 191-199. doi: 10.1016/00319384(84)90099-4

Stuphorn, V., Bauswein, E., and Hoffmann, K.-P. (2000). Neurons in the primate superior colliculus coding for arm movements in gazerelated coordinates. J. Neurophysiol. 83, 1283-1299.

Stuphorn, V., Hoffmann, K.-P., and Miller, L. E. (1999). Correlation of primate superior colliculus and reticular formation discharge with proximal limb muscle activity J. Neurophysiol. 81, 1978-1982.

Udo, M., and Mano, N. (1970). Discrimination of different spinal monosynaptic pathways converging onto reticular neurons. J. Neurophysiol. 33, 227-238.

Ugolini, G. (1995). “Transneuronal tracing with alpha-herpesviruses: a review of the methodology," in Viral Vectors, eds M. Keplitt and A. D. Loewy (New York, NY: Academic Press), 293-317.

Ugolini, G. (2010). Advances in viral transneuronal tracing. J. Neurosci. Methods 194, 2-20. doi: 10.1016/j.jneumeth.2009.12.001

Waldron, H. A., and Gwyn, D. G. (1969). Descending nerve tracts in the spinal cord of the rat. I. Fibers from the midbrain. J. Comp. Neurol. 137, 143-154. doi: 10.1002/cne. 901370203

Werner, W. (1993). Neurons in the primate superior colliculus are active before and during arm movements to visual targets. Eur. J. Neurosci. 5, 335-340.

Werner, W., Dannenberg, S., and Hoffmann, K.-P. (1997a). Armmovement-related neurons in the primate superior colliculus and underlying reticular formation: comparison of neuronal activity with EMGs of muscles of the shoulder, arm and trunk during reaching. Exp. Brain Res. 115, 191-205.

Werner, W., Hoffmann, K.-P., and Dannenberg, S. (1997b). Anatomical distribution of armmovement-related neurons in the primate superior colliculus and underlying reticular formation 
in comparison with visual and saccadic cells. Exp. Brain Res. 115, 206-316.

White, B. J., and Munoz, D. P. (2011). "The superior colliculus," in The Oxford Handbook of Eye Movements, eds S. P. Liversedge, I. D. Gilchrist, and S. Everling (Oxford: Oxford University Press), 195-213.

Xiulai, G., Yaliang, C., Yuping, M., and Qunyuan, X. (1994). Tectospinal projections to the spinal cord in the rabbit. J. Cap. Med. Univ. 15, 5-8.

Yang, H.-W., and Lemon, R. N. (2003). An electron microscopic examination of the corticospinal projection to the cervical spinal cord in the rat: lack of evidence for cortico-motoneuronal synapses. Exp. Brain Res. 149, 458-469. doi: 10.1007/s00221-003-1393-9

Yang, M., Card, J. P., Tirabassi, R. S., Miselis, R. R., and Enquist, L. W. (1999). Retrograde transneuronal spread of pseudorabies virus in defined neuronal circuitry of the rat brain is facilitated by $\mathrm{gE}$ mutations that reduce virulence. J. Virol. 73, 4350-4359.

Yasui, Y., Ono, K., Tsumori, T., Yokota, S., and Kishi, T. (1998). Tectal projections to the parvicellular reticular formation and the upper cervical spinal cord in the rat, with special reference to axon collateral innervation. Brain Res. 804, 149-154. doi: 10.1016/S00068993(98)00664-7

Conflict of Interest Statement: The authors declare that the research was conducted in the absence of any commercial or financial relationships that could be construed as a potential conflict of interest.

Received: 12 March 2012; accepted: 22 May 2013; published online: 07 June 2013.
Citation: Rubelowski JM, Menge $M$, Distler $C$, Rothermel $M$ and Hoffmann K-P (2013) Connections of the superior colliculus to shoulder muscles of the rat: a dual tracing study. Front. Neuroanat. 7:17. doi: 10.3389/fnana.2013.00017 Copyright (C) 2013 Rubelowski, Menge, Distler, Rothermel and Hoffmann. This is an open-access article distributed under the terms of the Creative Commons Attribution License, which permits use, distribution and reproduction in other forums, provided the original authors and source are credited and subject to any copyright notices concerning any third-party graphics etc. 